\title{
The Accounting Profession and the Female Gender in Ghana
}

\author{
Ernest Bruce-Twum \\ Central Business School \\ Central University College -Ghana \\ P. O. Box AN 16900, Accra-North
}

Tel: 233-0262-000-772Ｅ-mail: ertwum@yahoo.com

Received: December 22, 2012

Accepted: January 17, 2013

Online Published: January 23, 2013

doi:10.5430/afr.v2n1p54

URL: http://dx.doi.org/10.5430/afr.v2n1p54

\begin{abstract}
The paper seeks to find out whether female chartered accountants in Ghana have encountered the "glass ceiling". The research further explores the ability of the female accountant to balance her work and home lives. The paper also examines the role of the individual chartered accountant in the choices she makes. Finally, the paper seeks to find out the trend of female chartered accountants admitted into membership of the Institute of Chartered Accountants Ghana, from the commencement of Chartered Accountancy examination in Ghana.

In order to achieve the above objectives, the researcher collected data through the use of questionnaires and personal interviews. All the respondents and interviewees were members in good standing with the Institute of Chartered Accountants Ghana as at June 2012. A sample of 70 women and 3 men were used for the study.

The researcher found that, there is a steadily increments in the number of females admitted into membership of the Institute of Chartered Accountants Ghana every five years. However, none of the sample selected was in the top hierarchy of their respective jobs. It was also noted that the positions of those in industry was higher than their colleagues in practice. Various reasons have been assigned by individuals as accounting for factors why they are not at the top positions in their organizations.
\end{abstract}

Keywords: Gender, Glass ceiling, Ghana, Chartered accountant

\section{Introduction}

Many people in Ghana and the world generally assume the accounting profession as one reserved for men (Kirkham, et al. 2008). The profession undoubtedly, is one of the physically, socially and psychologically tasking professions in the world today. It demands the practitioner to be able to unravel all challenges of development and the outcome of its practice is under regular scrutiny by the general public (Sarfoh, 2010). During the early 1980s, certain jobs were considered unsuitable for a woman trainee due to the attitudes and /or culture of the clients' premises and these were allocated exclusively to males thereby limiting the range of work experience and opportunities for the few women in the office (Kirkham, et al. 2008). For one to be successful, demands a high level of dedication and an awareness of the remit prior to the onset of the requisite training.

According to Westcott and Seiler (1986), women have been accepted into the accountancy profession in all industrialized countries. Their technical qualification is apparent but a number of questions remain concerning their ability to perform demanding task required for the success of the profession. In Ghana many women have taken up the accounting profession and have attained the Chartered Accountant (CA) designation. However the researcher did not find any research into the career progression of the female accountant, in both practice and industry. Research conducted in other countries on the career progression of female accountants suggest that societal factors can militate against the progression of women in their accountancy carriers and the female accountants have to overcome more obstacles in their personal and work lives than their male counterparts ( Twomey, et al.2002).

The researcher was motivated to work on this paper because of scanty literature on the role of gender in accounting in developing nations such as Ghana. This research was thus carried out to gain direct experiences of women in accounting and to give voice to the silenced to contribute to the literature on gender studies in accounting.

According to Kirkham, et al.2008, women now succeed in a wide range of activities; girls achieve better results than boys at many levels yet this poses a number of problems for women who go far but still hit a metaphorical 'glass 
ceiling' and thus experience injustices in their ultimate achievement levels. As a result of these injustices, there are women accountants who do not aspire or desire to be admitted into partnership (Maupin, 1993a; Greenhause, et al 1997). Despite the gains achieved in general approach to women, evidence from UK according to Gammie, 2007 shows that it still remains difficult for women to progress to partnerships and the most senior positions in the profession. On the other hand, work done in the public service shows that whilst some women are able to break the glass ceiling there is some evidence that they simply make it to a glass cliff (Kirkham, et al. 2008). That is defined by Nutley, (2005) to mean that, when they reach the top they are more likely to lose their jobs when things go wrong, than is the case for their male colleagues.

The question remains as to why there are not many females in the top management positions. Is it because of the perceived glass ceiling? Or they accept this 'faith' position because there is a "glass ceiling" somewhere, which is preventing the female accountant from reaching the top in organizations. The essentialist perspective proposes that it is woman herself, who is the problem, due to her differences (often biological) from man. Acker $(1990,1992)$ suggests that it is the constructed nature of gender and gender in organization that is problematic. The roles of the individual herself have often been played to the side line.

The aim of this paper therefore is to examine:

$>$ Whether female accountants in Ghana have encountered the "glass ceiling"

$>$ The ability of the female accountant to balance their work and home lives

$>$ The independent role of the female accountant in the life choices they make

$>$ The trend of females who qualified yearly, from the commencement of Chartered Accountancy examination in Ghana

\section{Research Method}

The empirical material for this study was collected through the use of questionnaires and personal interviews. All the respondents and interviewees were members in good standing with the Institute of Chartered Accountants Ghana as at June 2012. The Institute of Chartered Accountants, Ghana was established by an Act of parliament, Act 170, in 1963. It is the sole body charged with regulation of Accountancy profession in Ghana. Its members are the only persons in Ghana, recognized under the Companies Code (Act 179) 1963, for the purpose of audit of company accounts. It is governed by a council of eleven Chartered Accountants, made of Nine Males and Two Females. The council as at June 2012 is led by a female as the president.

The Chartered Accountant Ghana qualification is recognized throughout Africa, as well as most European countries.

The Institute as at December 2012 runs two programs

- The Professional Program

- The Technicians Program

A candidate, upon successful completion of the Technicians program, will be entitled to write the designation "GAT". In the case of the professional program the candidate upon completing a period of training approved by the council, in accountancy, will be entitled to write the designation letter "CA" after his/her name.

For the purpose of this paper, the researcher restricted the study to persons with CA only.

The following membership data provides an interesting insight into the female membership of ICA(Ghana).The total membership, as at June 2012, stood at 2,161. (www.icagh.com; retrieved $4^{\text {th }}$ August 2012). The number of female members has also increased rapidly since the Institute turned out its first female graduate in 1975.In order to study the trend of female graduates, the researcher grouped the results in five yearly intervals, in order to make the better presentation and facilitate easy analysis. The trend of female graduates each year since the inception of the institute is shown on figure 1.The trend indicates constant increases in the number of female graduates every five years. The female members stood at 202 as at June 2011; representing about 9\% of Chartered Accountants members in good standing. These women were located across Ghana.

\section{Insert Figure 1 here}

A questionnaire survey was administered to the sample of ICAS members in Accra only. A total of 70 women and 3 men were used for the study. The researcher included men because he wanted to find out the perspective of men particularly in relation to women encountering the 'glass ceiling'. A list of women accountants was obtained from 
the Institute and telephone calls were made to selected interviewees requesting their permission for their inclusion in the study.

The researcher selected twenty women in practicing firms, three in academia and the rest in industry. Majority of the members in industry were from SSNIT and the Accountant Generals Department. Few Members in the private sector were included in the study. Personal narratives of interviewees was analyzed and used for the study. Personal narrative is used infrequently in accounting research although it can make the participants' lives or carriers more intelligible-linking disparate elements together and connecting individual lives to broader aspects of humanity (Haynes, 2006).

According to Riesman (2006) the interpretations intended or conceived by the narrator may not be the interpretation made by the audience, resulting in contested meanings. Notwithstanding the fact that this could pose as a limitation of the study, contested meaning can surface alternative meaning that address the non-obvious and aid in making sense of career (Alvesson and Deet, 2000).

Out of the total questionnaire of 70 sent to females, 64 representing 91 per cent of responses were received.100 per cent responses were received from the male counterpart, and used for the study. The Ages of the respondents were not considered for this paper.

\section{Analysis of Results}

\subsection{Has the female accountant encountered the 'glass ceiling' in Ghana?}

International studies conducted on females in Accountancy have shown that women are rare in upper levels of practice and industry (Wallace, 2009). Women face barriers to progression within organization, barriers which are not faced by their male counterparts. In many countries, while women are gaining managerial experience they still encounter a 'glass ceiling' (Twomel et al, 2002).

Linehan, et al.(2002) describes a 'glass ceiling' as a barrier so subtle that it is transparent, yet so strong that it prevents women and minorities from moving up the managerial hierarchy. It is a term used to describe the invisible barriers of promotion experienced by women in the course of their careers. Wallace (2009), pointed out that after more than three decades of research on women in organizations and the debate on the lack of advancement of women, questions still remains why there are not more women in senior management positions.

The questionnaire results of the positions of the respondents have been separated into members in practice and industry to facilitate better analysis. These are depicted on tables 1 and 2 below.

\section{Insert Table $1 \& 2$ here}

The results from both tables indicate that none of the respondents were in the Top positions in their respective jobs, despite the fact that they had between three to twenty two years post qualification working experience. Four of the respondents, in one of the "big four" audit firms in Ghana pointed out that ever since the firms commencement in Ghana more than forty years ago, they have had only one female partner. Most of the respondents' pointed out that most women perceive accounting as a difficult area and for that matter only few enter into the profession.

The questionnaire results indicate that a Chartered Accountant in most audit firms commences work at the Senior Audit level. It further indicate that though there is no special regulation in these firm that prevents females from moving up to the top, most of them who opt to stay in practice, end up at the assistant manager level. All the interviewees agreed that moving to the top positions was a very daunting task. As one interviewee explained:

Going up to partner level is climbing mountain Afadjato, even if you qualify, you can't get there. There is some kind of hindrances and politics within our firm... (Gloria).

The interviewees pointed out that most female accountant move to either industry to work or join others in setting up practicing firms. The female accountant believes that she has to overcome more obstacles than male counterparts in order to get to the top. These findings are consistent with that of the literature relating to 'glass ceiling' generally. Barcelona et al, (1975) found that women in business were motivated by the same factors as men yet something pulled women away from public accounting firms shortly after they attained the accounting designation.

Even though age was not considered in the study, some of the respondents, however made indicated that the young female accountant in their mid twenties, seem to be rising faster through the ranks than the older ones above thirtyfives years.

The position of the female accountant in industry seems to be better than their colleagues in practice. As shown on table 2, most of the respondents have risen through the ranks to Manager and Senior Manager Levels. As per the 
ranks of organizations the Chartered Accountant starts from the rank of assistant manager, and moves up the ladder to senior manager level, where there are nine levels, before moving up to the General Manager rank. Members in industry argue that even though the top is heavy, with determination and perseverance, as characterized by their profession, one can get to the top level.

In the private sector, there seem not to be too much bottlenecks moving up the ladder. Most of the respondents pointed out that, it is due to the size of the companies, and how dedicated and hard working the female accountant is. Various reasons were advanced by the respondents as to why female accountants are not seen much at the top or senior levels. The results are summarized on table 3 below.

Insert Table 3 here

From table 3 above, it seems that individual women had various perceptions accounting for their absence in top positions. On the contrary, some of the men interviewed believe that it is women themselves that had caused their absence. They argue that most women fail to take up opportunities and /or express reluctance to take up certain opportunities that come their way. This assertion had been debunked by Gender Advocates like Sarfoh, (2010), who argued that, women are not given equal chance of advancing like the men.

Despite these perceived bottlenecks, some few women had been able to make it to the top echlons; notable amongst them is the current President of Institute of Chartered Accountants Ghana Council Mrs. Angela Persah. Mrs. Cecelia Nyan also rose through the ranks to become a partner in Deloitte and Touche Ghana, and later the President of Council of the Institute of Chartered Accountants Ghana. In industry some remarkable improvements had been achieved.

\subsection{Influence of the Individual female accountant}

The responses of the respondents as summarized on table 3, raise the question as to what role is played by the individual female accountant in her bid to move up to senior levels. Is it that the female Accountant cannot personally take decisions that affect her upward movement to senior management level?

The female accountant ought to blame herself and not the system. The female accountant should be seen to be an independent person with options. The individual should take responsibility for what she makes of her life. The female accountant should be seen as a free agent who makes her own choices. According to de Beaviour, (1989), when a woman is free, "she has no other destiny than what she freely creates for herself". A woman who chooses to pursue admission to partnership in an accounting firm or to pursue a senior position in an organization as her career goal must actively pursue that goal and not rely solely on the actions of others to get her there.

Ninety percent of the respondents believe that though they had the perception that the accounting profession was a difficult one, they were however motivated by themselves to pursue it to the highest level. Thus despite the challenges they went through during the professional exams to qualify, they are as well unperturbed, by the 'glass ceilings' they believe they encounter, they will persist till they get to the highest level in their chosen career.

Minority of the respondents commented that the frustrations in the accounting profession is too much, in view of that they were looking for options to move out:

You are looked down by the men, and that whatever, you do they seem not to be satisfied.

I am old now to start a new career, had it not been for my age, I would have stopped the accounting job, and find something else to do. I believe that, the young ones who have personal options available to them, soon move out of practice to industry or to different professional fields.

The findings suggest that persons in private practice constantly look for options to get out of the profession, the choice or decision made is a personal one. Thus the individual contributes to the risk of not getting to partner or senior levels in both practice and industry.

\subsection{The ability of the female accountant to balance their work and home lives}

Research from other countries such as China, Ireland and UK, indicated that most women especially married ones find it very difficult to balance their work and home lives. The researcher thus sought the views of the respondents. $95 \%$ of the respondents were married woman, $3 \%$ were single parents and $2 \%$ unmarried.

Stockard, (1990) observed that, the apparent conflict between family and an accounting career appears to be negatively impacting the retention of women in public accounting. Typically, accounting entails long working hours, travel, and stressful business environment. For most women, these negative factors are intensified by family obligations and the pressures of striving for acceptance in a traditionally male-dominated profession. 
Balancing work and personal/family issues is a difficult thing to do and many times there is a sense that a good balance is not being accomplished Adair, (1999).

Gallhofer, et al. (2011) observed that, women who worked part-time or had other flexible working arrangement appeared to have made their work-lifestyle choices given preferences for combing motherhood and employment. Structural constraints impacting upon their work-lifestyle choices were experienced by several women who would have preferred to work part-time but could not do so because their employer did not offer this option.

The findings from the research collaborates the above literature. Majority of the respondents $(57 \%)$ stated that married women find it very difficult to balance work and family life while $43 \%$ stated otherwise.

Majority of the respondent indicated that they felt the family was their first priority. Ruby explained how family life completely changed her attitude to work:

In spite of all the work load and stress at the office, I have to get to market on Saturdays, cook for the week, make all the errands for home, and plan what we have to eat on a day to day basis. This situation is even made worse, where sometimes I had to pick up the child from school around 4.pm, which means I have to close early on those days. When you close that early in the accounting profession, you are not considered to be a serious worker.

Another respondent wrote as follows:

I have four children, each time I give birth I take a minimum of three months maternity leave, and when I resume, I have to close early to go and take care of the baby. My children are two years interval, if I have gone through this circle for eight or nine years, how do you expect me to be promoted within these years?(Esther)

The sentiment of the above woman seem to confirm Davidson and Cooper, (1992) assertion that single female workers "are taken more seriously" and hence, promoted more readily whereas a married individual cannot devote a lot of extra time and commitment to the job and this is what builds any career.

One interviewee posed a rhetoric question:

Imagine your wife with three children is asked to go for audit outside Accra for one week, and this is repeated every two weeks, how would you feel? Will you allow her to continue with this profession?

From the responses, it seems most of the women acknowledge that the difficulty encountered combining work and family lifestyle, had made most of them made choices that have impacted upon their ambition and career.

It appears to be able to balance and excel in your work and home at the same time will be trying to be super-woman. The accounting profession, demands long hours of work, as such most women feel they are neglecting their children when at work, and also neglecting work when they are with their children.

Some of the respondents acknowledged that their emphasis has shifted from been a career woman to a mother. For example, one woman said:

I currently have two children, if they become three, I will stop this accounting profession, and either teach or trade so I can take care of my children. My family is more important to me than my work.

Most of these findings collaborate with findings in other parts of the world. For example, Gallhofer, et al. (2011) found that where they can female ICAS members often prefer to work part-time rather than full-time in order to combine work and home lifestyles effectively.

\section{Conclusion}

From the above findings, one is apt to conclude that the female ICAG members in Ghana like in other countries have encountered issues/problems that prevent most of them from getting to senior levels in management, yet some few have been able to break the "glass ceiling". It was also noted that the individual female professional, has a personal role to play to get to the top level. Again, it was observed that becoming a mother is an important turning point in the career of a woman. However, this implies that women would have to reorganize their professional life and making a choice of what place will be given to family and what place to work. Finally, the researcher found out that the number of female graduates admitted into membership of the Institute of Chartered Accountant Ghana, on yearly basis seems to be increasing. However there is much room for improvement in the number, and positive steps should be taken to encourage women in accountancy. To this end, the Association of Women Accountants in Ghana (AWAG) led by Ms. Helen Buafo, should increase its advocacy role it has been championing over the years. 


\section{References}

Acker, J. (1990). "Hierarchies, jobs, and bodies: a theory of gendered organizations", Gender \& Society, Vol. 4 pp.139-58. http://dx.doi.org/10.1177/089124390004002002

Adler, S., Laney J. and Packer M. (1993). Managing women: Feminism and power in educational management. Buckingam: Open University Press.

Alvesson, M., Deetz, S. (2000). Doing Critical Management Research, Sage, Thousand Oaks, CA.

Broadbent, J. and Kirkham, L. (2008). Glass ceilings, glass cliefs or new worlds? Revisiting gender and accounting. Accounting, Auditing \& Accountability Journal, Vol. 21, Iss: 4 pp.465-473. http://dx.doi.org/10.1108/09513570810872888

Colling, Trevor and Dickens. (1998). Selling the case for gender equality; deregulation and equality bargaining. British Journal of Industrial Relations, 36(3), 389.

Cullen, Deborah L. and Luna Gaye. (1993). Women mentoring in academe: Addressing the gap in higher education. Gender and Education, 5(2). http://dx.doi.org/10.1080/0954025930050201

Davidson, M. \& C. Cooper. (1992). Shattering the Glass Ceiling: The Woman Manager.

De Beauvoir, S. (1989). The Second Sex, Vintage Books, New York, NY, (translated by H.M. Parshley, original work published in 1949).

Gallhofer, S., Catriona, P., Roberts,C., Tarbert,H. (2011). Preferences, constraints and work-life choices: the case of female Scottish chartered accountants, Accounting, Auditing \& Accountability Journal, Vol.24 Iss: 4 pp 440-470. http://dx.doi.org/10.1108/09513571111133054

Gammie, E.,Gammie, B Matson, M \& Duncan, F. (2007). Women of ICAS Reaching the Top: The Demise of the Glass Ceiling, the Institute of Chartered Accountants of Scotland, Edinburgh.

Haynes, K. (2006). "Linking narrative and identity construction: using autobiography in accounting research", Critical Perspectives on Accounting, Vol. 17 pp.399-418. http://dx.doi.org/10.1016/j.cpa.2004.08.005

Institute of Chartered Accountant Ghana (2012). [Online]: available: www.icagh.com/ about us (accessed August 4, 2012).

Pak, A. and Windsor, C. (2006). The effect of gender and dependent children on professional accountants' career progression. Critical Perspectives on accounting, Vol. 17,Iss:6 pp 828-844.

Paul Chapman, London Hantrais, L. (1995). A comparative perspective on gender and accountancy. The European Accounting Review, Vol. 4 No. 2, pp 197-215. http://dx.doi.org/10.1080/09638189500000011

Maupin, R. (1993). How can women's lack of upward mobility in accounting organizations be explained? Group and Organization Management, vol. 18, pp132. http://dx.doi.org/10.1177/1059601193182002

Nutley, S. and Mudd, J. (2006). Has the glass cliff replaced the glass ceiling for women employed in the public sector?, Public Money and Management, Vol.25 No. 1,pp3-4.

O’Neill, M., Bellamy, S., M. Jackson, \& C. Morley. (1998). Women in accounting: professional participation and career progression, Accounting Research Journal, vol. 11, pp387-399.

Roberts R.W and Dwyer D.P. (2004). the contemporary gender agenda of the U.S public accounting profession: embracing feminism or maintaining empire? Critical Perspectives on Accounting, Vol. 15, pp159-177. http://dx.doi.org/10.1016/S1045-2354(03)00003-0

Sarfoh O. R. (2010). Promoting women's participation and bridging gender gaps in the profession and public life-achievements, relevance and prospects; a civil engineers' perspective. The gender perspective.

Twomey A.M, Linehan M \& Walsh S.J. (2002). Career progression of young female accountant: evidence from the accountancy profession in Ireland, Journal of European Industrial training, Vol. 26, pp 117-124.

Wallace P. (2009). Career stories of women professional accountants, examining the personal narratives of career using Simon de Beauvoir's feminist existentialist philosophy as a theoretical framework, Qualitative Research in organizations and management, Vol. 4, No. 1, 2009 pg 62-84. http://dx.doi.org/10.1108/03090590210421996 
Table 1. Position of respondents in Practice

\begin{tabular}{lcc}
\hline & Frequency & Percent \\
\hline Partner & 0 & 0 \\
Senior Manager & 0 & 0 \\
Manager & 1 & 5 \\
Assistant Manager & 15 & 75 \\
Audit Senior & 4 & 20 \\
\hline Total & $\mathbf{2 0}$ & $\mathbf{1 0 0}$
\end{tabular}

\section{Source: Researchers own elaboration from field work}

Table 2. Position of respondents in Industry

\begin{tabular}{lcc}
\hline & Frequency & Percent \\
\hline & 0 & 0 \\
Director & 0 & 0 \\
General Manager & 7 & 16 \\
Senior Manager 1-9 & 28 & 64 \\
Manager & 7 & 16 \\
Deputy Manager & 2 & 4 \\
Assistant Manager & $\mathbf{4 4}$ & $\mathbf{1 0 0}$
\end{tabular}

Source: Researchers own elaboration from field work

Table 3. Causes of low number of female accountants at the Senior Levels

\begin{tabular}{llc}
\hline & Frequency & Percentage \\
\hline Fear to risk family security & 14 & 22 \\
Lack of confidence & 4 & 6 \\
Inability to work for long hours & 7 & 11 \\
Inflexible work schedules & 6 & 9 \\
Discrimination & 12 & 19 \\
Bottlenecks in Institutions & 21 & 33 \\
\hline Total & $\mathbf{6 4}$ & $\mathbf{1 0 0}$
\end{tabular}

Source: Researchers own elaboration from field work

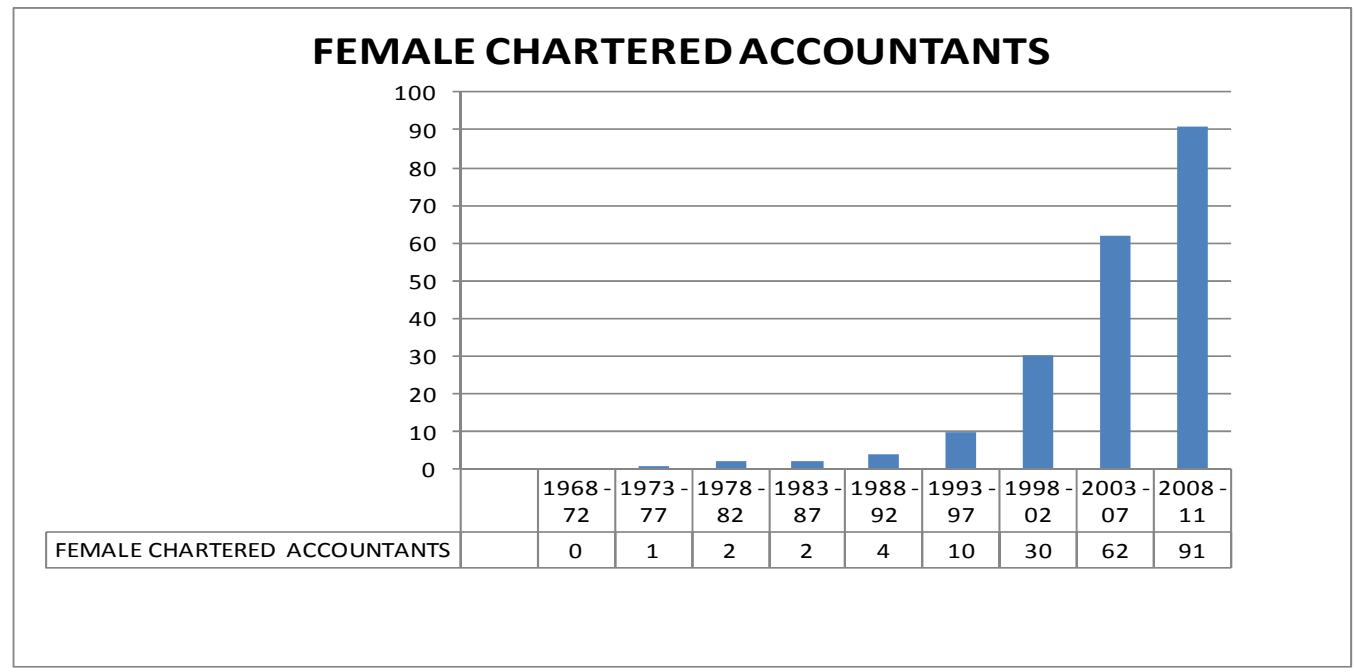

\section{Source: ICAG Graduation Brochure various years}

Figure 1. Female admission into membership of The Institute of Chartered Accountants Ghana (1968-2008) 